\title{
DIETARY FAT, SERUM CHOLESTEROL, AND ISCHÆMIC HEART DISEASE IN CEYLON
}

\author{
BY \\ IVOR OBEYESEKERE* \\ From the General Hospital, Colombo, Ceylon \\ Received September 2, 1963
}

The role of dietary fat in the pathogenesis of ischæmic heart disease has been the subject of increasing investigation and discussion in recent years. Keys $(1953,1956 \mathrm{a}, 1957)$ postulated that the diet, through its fat content, played an important role in the development of coronary heart disease; and that saturated fats, by increasing the serum cholesterol level, influenced atherogenesis and a tendency to develop thrombosis. This view has been supported, amongst others, by Jolliffe and Archer (1959) who have evaluated data based upon records of the World Health Organization and the Food and Agriculture Organization collected from 20 countries. They, too, stress the importance of the quality of dietary fat (i.e. saturated versus unsaturated). They showed that the death rate from degenerative heart disease was related statistically to the percentage of saturated fat in the diet. Ceylon is mentioned as a country where both fat intake and incidence of ischæmic heart disease are low. Some comparative figures are given in Table I.

This investigation has been undertaken to determine the possible ætiological factors in patients suffering from ischæmic heart disease in Ceylon, and deals with the fat intake and serum cholesterol of these patients and a discussion of the significance of the data. In addition data on the incomes of the patients were obtained, as in Ceylon diets are largely conditioned by the economic status of each individual.

TABLE I

Death Rates for Men Aged 55 to 59 Years and Environmental Factors for 6 Countries

\begin{tabular}{|c|c|c|c|c|c|c|}
\hline \multicolumn{3}{|c|}{ Country } & \multirow{2}{*}{$\begin{array}{c}\begin{array}{c}\text { Death rate per } \\
100,000 \text { from } \\
\text { arteriosclerotic and } \\
\text { degenerative heart } \\
\text { disease }\end{array} \\
704 \cdot 7 \\
577 \cdot 4 \\
588 \cdot 3 \\
103 \cdot 4 \\
427 \cdot 5 \\
122 \cdot 5\end{array}$} & \multirow{2}{*}{$\begin{array}{c}\begin{array}{c}\text { Average total } \\
\text { available daily } \\
\text { calories }\end{array} \\
3,070 \\
3,160 \\
3,130 \\
1,980 \\
3,270 \\
2,005\end{array}$} & \multirow{2}{*}{$\begin{array}{c}\begin{array}{c}\text { Total fat intake } \\
(\% \text { total calories) }\end{array} \\
\\
39 \cdot 2 \\
37 \cdot 9 \\
38 \cdot 0 \\
15 \cdot 2 \\
38 \cdot 4 \\
7.9\end{array}$} & \multirow{2}{*}{$\begin{array}{c}\begin{array}{c}\text { Daily fat intake } \\
\text { (g./day) }\end{array} \\
\\
134 \\
133 \\
132 \\
33 \\
140 \\
18\end{array}$} \\
\hline $\begin{array}{l}\text { U.S.A. } \\
\text { Australia } \\
\text { Canada } \\
\text { Ceylon } \\
\text { U.K. } \\
\text { Japan }\end{array}$ & $\begin{array}{l}\ldots \\
\cdots \\
\cdots \\
\cdots \\
\cdots\end{array}$ & $\begin{array}{l}\ldots \\
\cdots \\
\cdots \\
\cdots \\
\cdots\end{array}$ & & & & \\
\hline
\end{tabular}

The above figures are reproduced from Table I of the paper: "Coronary heart disease and dietary habits" by Jolliffe and Archer (1959). Column 5 has been calculated from the data in columns 3 and 4.

* Formerly General Hospital, Kandy. 


\section{Materials AND MethodS}

This study was based on 200 consecutive patients suffering from ischæmic heart disease treated personally at the Kandy General Hospital, and Nursing Home. Complete records of a further 18 patients treated during this period were not available and they were therefore excluded. The diagnosis was based on clinical findings confirmed in every case by positive electrocardiographic proof. All patients had at least one routine 12-lead electrocardiogram taken on admission and another on discharge. Where indicated, additional leads and more frequent tracings were taken. Serum glutamic oxalacetic transaminase (S.G.O.T.) estimations were made as a routine, soon after admission. Dietetic histories were obtained by a questionnaire, and details of the diet consumed each week per patient's family were noted, special inquiries on fatty foods being made: the daily intake per adult capita was then calculated. At least one serum cholesterol estimation was made in every patient. Thirty-six normal controls between the ages of 30 and 60 years were drawn from male subjects among hospital employees, blood donors, and volunteers.

\section{RESULTS}

The age and sex distribution of the patients are shown in Table II. Of the 200 patients, there were 180 men and 20 women, a ratio of $9: 1$. The maximum incidence occurred between 51 and 60 years. The average daily fat consumption per patient for the whole series was $55 \mathrm{~g}$. The individual fat consumption was found to bear a distinct relation to the family monthly income and the income per head per day as shown in Tables III and IV.

Most of the fat consumed was saturated fat: in the lower income group this came mostly from coconut (extensively used in cooking); in the higher income groups, there was a proportionate increase in animal fats and dairy produce.

TABLE II

Age and Sex Distribution of 200 Patients Suffering from Ischemic Heart Disease

\begin{tabular}{c|c|c}
\hline \multirow{2}{*}{ Age-group (yr.) } & \multicolumn{2}{|c}{ No. of patients } \\
\cline { 2 - 3 } & Men (180) & Women (20) \\
\hline $20-30$ & 1 & 0 \\
$31-40$ & 18 & 2 \\
$41-50$ & 45 & 5 \\
$51-60$ & 82 & 8 \\
$61-70$ & 27 & 5 \\
$71-80$ & 6 & 0 \\
Over 80 & 1 & 0 \\
\hline
\end{tabular}

TABLE III

Average Fat Consumption of the Adult Related to the Family Monthly Income ( $£ 1=$ Rs 13.33 cents)

\begin{tabular}{c|c}
\hline Family income per month (rupees) & $\begin{array}{c}\text { Average daily fat consumption } \\
(\mathrm{g} .)\end{array}$ \\
\hline$<100$ & 40 \\
$100-250$ & 49 \\
$251-500$ & 65 \\
$>500$ & 81 \\
\hline
\end{tabular}


TABLE IV

Average Daily fat Consumption Related to Income Per Head Per Day (1 rupee=approx. 1s. 6 d.)

\begin{tabular}{c|c}
\hline $\begin{array}{c}\text { Income per head per day } \\
\text { (rupees) }\end{array}$ & $\begin{array}{c}\text { Average daily fat consumption } \\
(\mathrm{g} .)\end{array}$ \\
\hline$<1$ & 42 \\
$1 \cdot 01-2$ & 66 \\
$>2$ & 75 \\
\hline
\end{tabular}

TABLE V

Comparison of Serum Cholesterol of Male Patients, Irrespective of Age and Income Group, with Normal CONTROLS

\begin{tabular}{c|c|c}
\hline $\begin{array}{c}\text { Mean serum cholesterol } \\
\text { (mg./100 ml.) }\end{array}$ & $\begin{array}{c}\text { Normal control } \\
\text { (\% of subjects) }\end{array}$ & $\begin{array}{c}\text { Patients } \\
\text { (\% of subjects) }\end{array}$ \\
\hline$<200$ & 28 & 22 \\
$200-250$ & 64 & 50 \\
$>250$ & 8 & 28 \\
\hline
\end{tabular}

TABLE VI

Comparison of Serum of Male Patients according to Income Group Showing Percentage of Patients in Each Group

\begin{tabular}{c|c|c}
\hline $\begin{array}{c}\text { Income } \\
\text { (Rs/head/day) }\end{array}$ & Per cent of patients & $\begin{array}{c}\text { Serum cholesterol } \\
\text { (mg./100 ml.) }\end{array}$ \\
\hline$<1$ & 40 & $221 \cdot 2 \pm 41 \cdot 2$ \\
$1 \cdot 01-2$ & 28 & $247 \cdot 8 \pm 50 \cdot 2$ \\
$>2$ & 32 & $245 \cdot 1 \pm 47 \cdot 6$ \\
\hline
\end{tabular}

TABLE VII

Comparison of Serum Cholesterol of Patients and Controls by Age-group

\begin{tabular}{c|c|c|c|c}
\hline $\begin{array}{c}\text { Age-group } \\
\text { (yr.) }\end{array}$ & \multicolumn{2}{|c|}{ Normal controls } & \multicolumn{2}{c}{ Patients } \\
\cline { 2 - 4 } & No. & Mean & No. & Mean \\
\hline $31-40$ & 7 & $192 \cdot 6 \pm 18 \cdot 4$ & 16 & $241 \cdot 1 \pm 50 \cdot 3$ \\
$41-50$ & 17 & $209 \cdot 1 \pm 33 \cdot 5$ & 29 & $241 \cdot 3 \pm 42 \cdot 2$ \\
$51-60$ & 12 & $238 \cdot 4 \pm 23 \cdot 8$ & 57 & $234 \cdot 5 \pm 48 \cdot 4$ \\
$61-70$ & Nil & - & 21 & $219 \cdot 7 \pm 35 \cdot 7$ \\
\hline
\end{tabular}

Of the 200 patients, 56 consumed less than 40 g., 84 between 41 and 70 g., and 60 over $70 \mathrm{~g}$. The average serum cholesterol level of the men, $234.4 \mathrm{mg} . / 100 \mathrm{ml} .( \pm 46 \cdot 1)$, was higher than in the normal group, $212 \mathrm{mg} . / 100 \mathrm{ml}$. $( \pm 49 \cdot 2)$ (Table V). As the income and fat consumption increased, the serum cholesterol of patients increased up to a limit. There was a statistically significant difference between the serum cholesterol of those earning less than one rupee, and those earning more (Table VI).

Statistically the serum cholesterol levels of patients in the fourth and fifth decades were significantly higher than those of the normal controls for the same age-groups. There was no significant difference between patients and controls in the sixth decade (Table VII). 


\section{DisCUSSION}

Much has been written about the role of dietary fat as a cause of ischæmic heart disease and atherosclerosis. The evidence is mainly of an epidemiological nature, and vital statistics and statistics concerning food habits gathered from different countries have been used to support this theory. The inherent dangers and fallacies in this form of evidence have already been referred to by Yudkin (1957, 1959), and by Yerushalmy and Hilleboe (1957). The specific mortality figures derived from death certificates are subject to limitation and great variation from country to country. Accuracy of certification depends on the quantity and quality of medical care, on local customs, on the systems of medicine adopted, and on the diagnostic habits of the medical profession. The percentage error in certification is so variable in different countries that the figures are not comparable. This point is well illustrated in the case of Japan: all workers are agreed that fat consumption amongst the Japanese is remarkably low, estimated at about $20 \mathrm{~g}$. fat a day, where the fats used are rich in unsaturated fatty acids, the normal mean plasma cholesterol national value being $210 \mathrm{mg} . / 100 \mathrm{ml}$. Keys (1956b) quoted vital statistics obtained from Japan to strengthen his hypothesis - the low incidence of coronary heart disease in keeping with the very low intake of dietary fat in the national diet. These findings are contradicted by Pollak (1959) who found a high incidence of atherosclerosis and cardiovascular disease in spite of an "anti-atherogenic diet" low in calories and fat. He found no evidence to support the concept that high levels of plasma cholesterol were atherogenic. Gore, Hirst, and Koseki (1959) made a comparative study of aortic atherosclerosis in the United States, Japan, and Guatemala, and concluded that, in view of the comparatively low incidence of fatal coronary artery disease in Japan and the relatively low levels of serum cholesterol amongst the Japanese, it was surprising not to find a more striking difference in the aortæ between the U.S. and Japan. Schroeder (1958) found atherosclerosis involving coronary arteries very common in Japan; myocardial infarction accounted for a large percentage of sudden deaths and was common at necropsy.

In like manner, the low death rate from ischæmic heart disease in Ceylon $(103.4$ per 100,000 for males aged 55-59 years) mentioned in the United National Organization data (Joliffe and Archer, 1959) does not give a true picture of the prevalence of the disease in the country. It is a common disease among men over 30 years, and recent vital statistics from Ceylon show that heart disease is the chief cause of death in men over 30 years of age, and, of the specific causes mentioned, arteriosclerotic and degenerative heart disease is by far the most common (Table VIII). This fact is also borne out by morbidity statistics as shown by the number of in-patients treated in hospitals. Excluding patients suffering from infectious fevers, acute respiratory disorders, dysentery (amœbic and bacillary), anæmia, and malnutrition, ischæmic heart disease and its complications are the leading diseases for which men over 30 are admitted.

A study of Table VIII also illustrates some of the fallacies and dangers of relying on vital statistics. For instance, 8121 deaths were attributed to "senility without mention of psychosis, ill-defined and unknown causes" (B45) and represent 33 per cent of all deaths in men over 30 years. 1333 deaths were attributed to "other diseases of the heart" (B27). The nature of the diseases included under this heading, which are responsible for $\mathbf{4 5}$ per cent of cardiac deaths recorded, is less certain. Bacterial endocarditis is uncommon in this age-group, and cardiomyopathy and endomyocardial fibrosis are rare in Ceylon (the common causes are listed separately). If heart diseases of unknown cause were added to degenerative and atherosclerotic heart disease and were due (as they could be) to ischæmic heart disease, the incidence of coronary artery disease would appear very much higher. Therefore, these figures give no idea of the prevalence of ischæmic heart disease.

The average daily fat consumption per patient in this study was $55 \mathrm{~g}$. and bore a direct relation to the economic status of the individual, the fat being mainly saturated fat. Broadly, there were three economic levels (Table IV) and the average fat consumption was 42,66 , and $75 \mathrm{~g}$. respectively. These findings were similar to the results of Cullumbine, Bibile, and Wikramanayake (1949) who made a dietetic survey of the various communities in Ceylon (373 families) in 1949. They too found 
TABLE VIII

Chief Causes of Death in Men over 30 Years of Age in Ceylon

\begin{tabular}{|c|c|c|c|c|c|c|c|c|c|c|c|c|c|}
\hline \multirow{2}{*}{ Causes of death } & \multicolumn{13}{|c|}{ Age-group (yr.) } \\
\hline & $30-34$ & $35-39$ & $40-44$ & | 45-49 & $50-54$ & $55-59$ & $60-64$ & $65-69$ & $70-74$ & 75-79 & $80-84$ & $85+$ & Total \\
\hline All causes. & 815 & 1018 & 957 & 1502 & 1535 & 2076 & 2200 & 2614 & 2696 & 2241 & 2309 & 4080 & 24,043 \\
\hline $\begin{array}{l}\text { 1uberculosis of } \\
\text { respiratory system } \\
\text { (B1) }\end{array}$ & & & 05 & $10 ?$ & & & & & & & & & \\
\hline $\begin{array}{l}\text { Malignant neo- } \\
\text { plasms, including } \\
\text { neoplasms of lym- } \\
\text { phatic and hæmato- }\end{array}$ & 63 & 18 & 85 & 102 & 100 & 104 & 92 & 80 & 62 & 31 & 14 & 15 & 938 \\
\hline poietic tissues (B18) & 36 & 44 & 52 & 100 & 134 & 164 & 97 & 140 & 76 & 61 & 29 & 25 & 958 \\
\hline $\begin{array}{l}\text { Anæmias (B12) } \\
\text { Rheumatic fever }\end{array}$ & 40 & 30 & 47 & 77 & 85 & 116 & 110 & 150 & 113 & 103 & 63 & 58 & 992 \\
\hline $\begin{array}{l}\text { Rheumatic fever } \\
\text { (B24) ... }\end{array}$ & 3 & 6 & 2 & 6 & 5 & 5 & 14 & 18 & 22 & 18 & 17 & 13 & 129 \\
\hline $\begin{array}{l}\text { Chronic rheumatic } \\
\text { heart disease (B25) } \\
\text { Arteriosclerotic and }\end{array}$ & 3 & 4 & 9 & 2 & 3 & 9 & 5 & 6 & 7 & 6 & 7 & 10 & 71 \\
\hline $\begin{array}{l}\text { degenerative heart } \\
\text { disease (B26) }\end{array}$ & 31 & 35 & 45 & 99 & 132 & 162 & 156 & 173 & 179 & 103 & 89 & 96 & 1300 \\
\hline $\begin{array}{l}\text { Other diseases of } \\
\text { heart (B27) } \\
\text { Hypertensive heart }\end{array}$ & 50 & 69 & 66 & 123 & 137 & 189 & 168 & 181 & 133 & 81 & 76 & 60 & 1333 \\
\hline disease (B28) & 6 & $\begin{array}{r}4 \\
68\end{array}$ & $\begin{array}{r}7 \\
48\end{array}$ & 82 & 7 & $\begin{array}{l}16 \\
98\end{array}$ & 14 & $\begin{array}{r}15 \\
149\end{array}$ & $\begin{array}{r}7 \\
124\end{array}$ & $\begin{array}{l}13 \\
92\end{array}$ & $\begin{array}{r}4 \\
49\end{array}$ & $\begin{array}{r}4 \\
80\end{array}$ & $\begin{array}{r}102 \\
1023\end{array}$ \\
\hline $\begin{array}{l}\text { Senility without } \\
\text { mention of } \\
\text { psychosis, ill- } \\
\text { defined and un- } \\
\text { known causes }\end{array}$ & 34 & 08 & 48 & $\delta 2$ & 13 & 98 & 124 & 149 & 124 & & 49 & 80 & 1023 \\
\hline (B45) $\ldots$ & 62 & 96 & 90 & 150 & 154 & 207 & 365 & 553 & 980 & 1013 & 1432 & 3019 & 8121 \\
\hline (B48) $\ldots$ & 107 & 143 & 103 & 118 & 76 & 95 & 89 & 73 & 44 & 26 & 29 & 28 & 931 \\
\hline $\begin{array}{l}\text { Total deaths from } \\
\text { heart disease }\end{array}$ & & & & & & & & & & & & & 2935 \\
\hline
\end{tabular}

The above figures are reproduced from Annual Epidemiological and Vital Statistics, 1959 issued by the World Health Organization-Geneva (1962).

that the fat content of diets varied with the economic levels of families, and the respective fat intakes were $38 \cdot 4,50 \cdot 7$, and $89.9 \mathrm{~g}$. It appears that the fat consumption of patients with ischæmic heart disease is similar to that of the population at large and has changed little since 1949. Compared with Western figures of 130 to $150 \mathrm{~g}$., this figure is extremely low: $56(28 \%)$ patients consumed less than $40 \mathrm{~g}$. and $140(70 \%)$ less than $70 \mathrm{~g}$. That dietary fat plays any role in the development of ischæmic heart disease in Ceylon therefore seems very unlikely; nor does it account for the increasing incidence of the disease.

In a study of serum cholesterol levels in the U.S.A., Orvis et al. (1961) found that the levels in patients suffering from coronary artery disease were considerably higher than those in normal controls. Moreover in patients with coronary disease, the level was raised to about the same degree irrespective of age; whereas in the normal groups, there was a gradual rise with increasing age. The mean cholesterol value for patients was $275 \mathrm{mg} . / 100 \mathrm{ml}$., and for controls 222 , 242, and 259 $\mathrm{mg}$. $/ 100 \mathrm{ml}$. for the fourth, fifth, and sixth decades. The mean serum cholesterol of patients in this series, $234 \mathrm{mg}$. $/ 100 \mathrm{ml}$., was higher than the normal control group, $212 \mathrm{mg}$. $/ 100 \mathrm{ml}$. These figures are low by American standards. Table V shows that only 56 patients $(28 \%)$ had a serum cholesterol above $250 \mathrm{mg} . / 100 \mathrm{ml}$. Thus, before serum cholesterol values can be used as an index of possible ischæmic heart disease in any given country it is important to establish a national 
norm for that particular country. In this investigation too, in the normal group there was a gradual rise with increasing age, while in the patient group the serum cholesterols were highest in the fourth and fifth decades, and showed a slight fall in the sixth and seventh decades. Further, there was a significant difference between the serum cholesterol levels of patients in the lower and upper income groups. The serum cholesterol of patients increased with income and fat consumption.

That serum cholesterol levels vary with fat consumption and age among the normal population, and also vary from country to country is fairly well established. It is also known that patients with ischæmic heart disease, especially in the younger age-groups, have higher serum cholesterol levels than normal controls. What actually causes this has yet to be established.

These results indicate that ischæmic heart disease is common in Ceylon despite the low dietary fat consumption. To believe that dietary fat plays any significant part in the causation of ischæmic heart disease is therefore difficult.

\section{SUMMARY}

The fat consumption of 200 patients suffering from ischæmic heart disease in Ceylon was estimated and found to be low compared with Western standards. The amount of fat consumed by these patients was similar to that noted in a survey on the normal population in Ceylon in 1949, and was likewise found to vary with income levels. It was thought that dietary fat did not play an important role in the ætiology of ischæmic heart disease which is common in Ceylon.

The serum cholesterol levels of the male patients were compared with those of a normal control group. The mean level of the patients was found to be significantly higher than that of the controls in the fourth and fifth decades, and varied with fat consumption and income levels. The serum cholesterol levels in Ceylon were, however, far below American figures. Indeed, a serum cholesterol level high for Ceylon would be considered low by American standards. There is, therefore, a need for establishing mean normal serum cholesterol levels for each country. It is thought that the raised serum cholesterol levels of patients, as compared with controls, cannot be explained by differences in fat consumption; the exact cause has yet to be determined. There is no evidence to support the theory that dietary fat causes ischæmic heart disease. On the contrary, it is difficult to believe that dietary fat plays any significant part in its causation.

I acknowledge the help received from Dr. G. U. de Silva who calculated the fat contents of the diets from the data in the histories. Nurse Anula Senanayake kept the records and tabulated the data. Mr. D. D. Jayatilleke and Dr. D. B. Gunasekera were responsible for the statistical analysis. The following housemen wrote the histories: Drs Balachandran, Jeeveratnam, Forbes, G. U. de Silva, Boteju, Rajapakee, and Neil de Soysa. Mr. Maheswaram, Biochemist, Kandy Hospital, estimated the serum cholesterol. I am deeply grateful to all of them, and also to Professor J. F. Goodwin for help with the manuscript.

\section{REFERENCES}

Cullumbine, H., Bibile, S. W., and Wikramanayake, T. (1949). A study of the diets of various Ceylonese communities. Ceylon J. med. Sci., (D), 6, 255.

Gore, I., Hirst, A. E., and Koseki, Y. (1959). Comparison of aortic atherosclerosis in the United States, Japan, and Guatemala. Amer. J. clin. Nutr., 7, 50.

Jolliffe, N., and Archer, M. (1959). Statistical association between international coronary heart disease death rates and certain environmental factors. J. chron. Dis., 9, 636.

Keys, A. (1953). Atherosclerosis: A problem in newer public health. J. Mt Sinai Hosp., 20, 118.

(1956a). The diet and the development of coronary heart disease. J. chron. Dis., 4, 364.

- (1956b). Diet and coronary heart disease. In World Trends in Cardiology, Vol. 1: Cardiovascular Epidemiology, ed. A. Keys, and P. D. White, p. 135. Paul B. Hoeber, New York.

(1957). Diet and the epidemiology of coronary heart disease. J. Amer. med. Ass., 164, 1912.

Orvis, H. H., Thomas, R. E., Fawal, I. A., and Evans, J. M. (1961). Serum cholesterol in normal males versus males with coronary heart disease: Differences with respect to age. Amer. J. med. Sci., 241, 167.

Pollak, O. J. (1959). Diet and atherosclerosis; variations on a theme. Amer. J. clin. Nutr., 7, 502.

Schroeder, H. A. (1958). Degenerative cardiovascular disease in the Orient. 1. Atherosclerosis. J. chron. Dis., 8, 287.

Yerushalmy, J., and Hilleboe, H. E. (1957). Fat in the diet and mortality from heart disease. N.Y. med. J., 57, 2343.

Yudkin, J. (1957). Diet and coronary thrombosis: hypothesis and fact. Lancet, 2, 155.

(1959). Etiology of cardiac infarction. Arch. intern. Med., 104, 681. 